NBER WORKING PAPER SERIES

\begin{abstract}
AN EMPIRICAL ANALYSIS OF COST RECOVERY IN SUPERFUND CASES: IMPLICATIONS FOR BROWNFIELDS AND JOINT AND SEVERAL LIABILITY
\end{abstract}

\author{
Howard F. Chang \\ Hilary Sigman \\ Working Paper 16209 \\ http://www.nber.org/papers/w16209
NATIONAL BUREAU OF ECONOMIC RESEARCH
1050 Massachusetts Avenue
Cambridge, MA 02138
July 2010

We wish to thank Soumyanetra Munshi for research assistance and Wendy Wagner, Michael Ward, and participants at the 2009 Conference on Empirical Legal Studies, at the 2009 meeting of the Latin American and Caribbean Law and Economics Association, at the 2010 meetings of the American Law and Economics Association, of the Society for Environmental Law and Economics, and of the World Congress of Environmental and Resource Economists, and at workshops at the University of Pennsylvania and at the University of Arizona for helpful comments. We developed this paper under STAR Research Assistance Agreement No. R831777, awarded by the U.S. Environmental Protection Agency (EPA), but the EPA has not formally reviewed this article. The views expressed in this paper are those of the authors, and neither the EPA nor the National Bureau of Economic Research necessarily endorse any products, views, or commercial services mentioned in this paper.

NBER working papers are circulated for discussion and comment purposes. They have not been peerreviewed or been subject to the review by the NBER Board of Directors that accompanies official NBER publications.

(C) 2010 by Howard F. Chang and Hilary Sigman. All rights reserved. Short sections of text, not to exceed two paragraphs, may be quoted without explicit permission provided that full credit, including (c) notice, is given to the source. 
An Empirical Analysis of Cost Recovery in Superfund Cases: Implications for Brownfields and Joint and Several Liability

Howard F. Chang and Hilary Sigman

NBER Working Paper No. 16209

July 2010

JEL No. K32,K41,Q53,Q58,R38

\begin{abstract}
Economic theory developed in the prior literature indicates that under the joint and several liability imposed by the federal Superfund statute, the government should recover more of its costs of cleaning up contaminated sites than it would under nonjoint liability, and the amount recovered should increase with the number of defendants and with the independence among defendants in trial outcomes. We test these predictions empirically using data on outcomes in federal Superfund cases. Theory also suggests that this increase in the amount recovered may discourage the sale and redevelopment of potentially contaminated sites (or "brownfields"). We find the increase to be substantial, which suggests that this implicit tax on sales may be an important deterrent for parties contemplating brownfields redevelopment.
\end{abstract}

\author{
Howard F. Chang \\ University of Pennsylvania Law School \\ 3400 Chestnut Street \\ Philadelphia, PA 19104-6204 \\ hchang@law.upenn.edu \\ Hilary Sigman \\ Department of Economics \\ Rutgers University \\ 75 Hamilton Street \\ New Brunswick, NJ 08901-1248 \\ and NBER \\ sigman@econ.rutgers.edu
}




\title{
AN EMPIRICAL ANALYSIS OF COST RECOVERY IN SUPERFUND CASES: IMPLICATIONS FOR BROWNFIELDS AND JOINT AND SEVERAL LIABILITY
}

\author{
HOWARD F. CHANG and HILARY SIGMAN*
}

In the United States, the Comprehensive Environmental Response, Compensation, and Liability Act (CERCLA), ${ }^{1}$ also known as the Superfund statute, makes certain specified parties potentially responsible for the costs of cleaning up a contaminated site. These potentially responsible parties (PRPs) may include the current owners and operators of such a site, generators and transporters of hazardous waste, and certain prior owners and operators of the site. ${ }^{2}$ Courts have interpreted CERCLA to impose joint and several liability on these PRPs for any indivisible harm caused by hazardous substances at the site. ${ }^{3}$ Joint and several liability allows the government to recover the full costs of cleanup at the site from any PRP, regardless of the PRP's equitable share of the liability.

* Howard F. Chang is the Earle Hepburn Professor of Law at the University of Pennsylvania Law School; Hilary Sigman is a Professor of Economics at Rutgers University and a Research Associate at the National Bureau of Economic Research. Copyright (C) 2010 by Howard F. Chang and Hilary Sigman. We wish to thank Soumyanetra Munshi for research assistance and Wendy Wagner, Michael Ward, and participants at the 2009 Conference on Empirical Legal Studies, at the 2009 meeting of the Latin American and Caribbean Law and Economics Association, at the 2010 meetings of the American Law and Economics Association, of the Society for Environmental Law and Economics, and of the World Congress of Environmental and Resource Economists, and at workshops at the University of Pennsylvania and at the University of Arizona for helpful comments. We developed this paper under STAR Research Assistance Agreement No. R831777, awarded by the U.S. Environmental Protection Agency (EPA), but the EPA has not formally reviewed this article. The views expressed in this paper are those of the authors, and the EPA does not endorse any products or commercial services mentioned in this paper.

${ }^{1} 42$ U.S.C. $\S \S 9601-75$ (2000).

${ }^{2}$ See id. § 9607(a).

${ }^{3}$ See, e.g., United States v. Alcan Aluminum Corp., 964 F.2d 252, 268-69 (3d Cir. 1992); O’Neil v. Picillo, 883 F.2d 176, 178-79 (1 ${ }^{\text {st }}$ Cir. 1989), cert. denied, 493 U.S. 1071 (1990); United States v. Monsanto Co., 858 F.2d 160, 171-73 ( $4^{\text {th }}$ Cir. 1988), cert. denied, 490 U.S. 1106 (1989). 


\section{HOWARD F. CHANG and HILARY SIGMAN}

This liability regime allows the government to recover the full costs of cleanup even if some of the PRPs are judgment-proof, because the other PRPs remain liable for the full amount. Advocates for joint and several liability argue that shifting these costs from the government to PRPs improves the incentives for those PRPs to avoid contamination of the property in question (Segerson, 1994, p. 266). Similarly, the breadth of the class of parties defined to be PRPs increases the number of liable parties and thereby reduces the probability that judgment-proof PRPs will limit the government's ability to recover its cleanup costs.

Joint and several liability under the Superfund law, however, has been controversial. Critics have advanced various proposals to limit the scope of this liability (Kornhauser \& Revesz, 1995, p. 115). In a recent Superfund case, the U.S. Supreme Court limited the scope of this liability by adopting a relatively narrow view of both the circumstances justifying joint and several liability and the parties subject to this liability. ${ }^{4}$

One influential objection to Superfund liability is the claim that the threat of this liability deters the acquisition of potentially contaminated sites for redevelopment. This claim has stirred widespread concerns about "brownfield" sites, which CERCLA defines as "real property, the expansion, redevelopment, or reuse of which may be complicated by the presence or potential presence of a hazardous substance, pollutant, or contaminant." 5 Many communities seek to encourage the redevelopment of these "brownfields" because these sites are considered not only sources of urban blight but also substitutes for the introduction of new industrial sites in suburban or rural locations, sometimes known as "greenfields." The use of greenfields would reduce open space, contribute to suburban sprawl, and require construction of new infrastructure.

A U.S. Conference of Mayors (USCM) survey found 95,000 acres of brownfields in 192 responding cities (USCM, 2003, p. 12). The USCM survey respondents listed "liability issues" as second only to "lack of clean up funds" as an obstacle to the redevelopment of these sites (USCM, 2003, p. 14). Similarly, a recent survey of private developers indicated that they consider protection from liability for cleanup costs to be a valuable incentive to buy and

\footnotetext{
${ }^{4}$ See Burlington N. \& Santa Fe Ry. Co. v. United States, 129 S. Ct. 1870 (2009).

${ }^{5} 42$ U.S.C.A. § 9601(39)(A) (West Supp. 2005).
} 


\section{COST RECOVERY IN SUPERFUND CASES}

to develop contaminated sites (Wernstedt et al., 2004, p. 17; Wernstedt, Meyer \& Alberini, 2006, p. 361).

Responding to the problem of brownfields, the U.S. Environmental Protection Agency (EPA), local communities, and developers have explored various ways to encourage the redevelopment of these sites. In 1995, the EPA announced that it would issue more "comfort letters" to assure owners engaged in cleanups that the EPA would not subject their properties to further CERCLA actions (Percival et al., 2003, p. 269). As part of its brownfields initiative, the EPA also sought to expand the use of "prospective purchaser agreements," whereby a prospective purchaser and the EPA enter a binding contract that includes a "covenant not to sue" the prospective purchaser under CERCLA. ${ }^{6}$ In 2002, the Small Business Liability Relief and Brownfields Revitalization $\mathrm{Act}^{7}$ amended the Superfund law to exempt a "bona fide prospective purchaser" from liability as an "owner" under CERCLA as long as the purchaser meets certain specified conditions. ${ }^{8}$

Moreover, each state has its own laws governing the cleanup of contaminated sites in addition to the federal Superfund law. Many state rules mimic the CERCLA liability provisions, including joint and several liability for owners and a broad set of other parties, but some states use different rules (Environmental Law Institute, 2002, pp. 32-33; Geltman, 1996, pp. 4-5). Most states also have their own brownfields programs, which offer various incentives for prospective purchasers and developers, including "comfort" or "no further action" letters and covenants not to sue (Geltman, 1996, p. 9).

Similarly, joint and several liability is both common and controversial in the environmental laws of other countries. Most members of the European Union and other members of the Organization for Economic Cooperation and Development, for example, rely on joint and several environmental liability to some extent but have also limited its scope (Clarke, 2001). Thus, an analysis of the effects of the federal Superfund regime in the United States provides not only the basis for an evaluation of that regime but also some guidance for both

\footnotetext{
${ }^{6}$ Announcement and Publication of Guidance on Agreements with Prospective Purchasers of Contaminated Property and Model Prospective Purchaser Agreement, 60 Fed. Reg. 34,792 (1995).

${ }^{7}$ Pub. L. No. 107-118, 115 Stat. 2356 (2002).

${ }^{8} 42$ U.S.C.A. § 9607(r) (West Supp. 2005).
} 
states and other countries considering whether to adopt laws and policies similar to those adopted by the U.S. government.

In Section I of this article, we survey results in the previous economic literature regarding the effects of joint and several liability and the implications of Superfund liability for brownfields. In Section II, we describe our data and our empirical test for the effects of joint and several liability under Superfund on settlement amounts and awards at trial. In Section III, we present our results. In Section IV, we discuss the implications of our results for the brownfields problem. In Section V, we conclude with some observations regarding the policy implications of our results for the Superfund liability regime.

\section{Previous Literature}

First, we will review the predictions in the economic literature regarding the effects of joint and several liability on the amount paid by defendants to the plaintiff. Second, we will review the literature on the brownfields problem. Some of the reasons for Superfund liability to discourage the purchase of contaminated property arise from the tendency of joint and several liability to increase the amount that the government can recover from PRPs through litigation or settlement. Most of these effects on brownfields arise because the purchase may increase the number of defendants in a suit to recover cleanup costs.

\section{A. The Effects of Joint and Several Liability}

The economic theory developed in the prior literature suggest various reasons to expect joint and several liability under the Superfund law to increase the recovery of cleanup costs by the government. First, this liability regime allows the government to recover the full costs of cleanup even if some of the PRPs are insolvent and thus judgment-proof (Segerson, 1994, p. 266). Second, even if all PRPs are solvent, joint and several liability would increase the government's expected recovery from litigation as long as the outcomes at trial are uncertain and not perfectly correlated across defendants (Kornhauser \& Revesz, 1995b, pp. 138-39). This result emerges because the government only needs to succeed against one defendant in order to recover all its cleanup 


\section{COST RECOVERY IN SUPERFUND CASES}

costs under joint and several liability. This effect increases in magnitude as the correlation in trial outcomes among the defendants falls.

Third, as shown by Easterbrook, Landes, and Posner (1980, pp. 354-60), even when outcomes at trial are uncertain and perfectly correlated across defendants, joint and several liability may increase the amount that the government can expect to recover through settlement compared to the expected outcome of litigation against all defendants. This result emerges from joint and several liability under CERCLA's "pro tanto" setoff rule, which reduces the government's claim against any nonsettling defendants by the amount paid by a settling defendant in the settlement, ${ }^{9}$ because the gain for the nonsettling defendants from this setoff tends to be too small to compensate for the loss flowing from the absence of the settling defendant at trial, where that defendant might share liability for any amount awarded by the court to the plaintiff. $^{10}$ This negative externality from settlement for nonsettling defendants creates a race to settle with the government, which the government can exploit to increase the total amount extracted from the defendants through settlement.

Furthermore, the amount that the government can extract in such a settlement increases as the number of defendants increases (Easterbrook, Landes \& Posner, 1980, p. 359). The case of one defendant represents the alternative of nonjoint liability insofar as joint and several liability can have no effect in the case of one defendant. Thus, an increase in the number of defendants from one to greater than one triggers all the effects of joint and several liability. In this sense, an increase in the settlement amount as the number of defendants continues to rise further is a generalization of the effect of joint and several liability.

In the absence of joint and several liability, we would observe none of these effects on the amount recovered by the government. In particular, without joint and several liability, as long as judgment-proof defendants do not constrain the amount recovered, we would not expect this amount to increase with the number of defendants. Instead, under these circumstances, the number of defendants would have no effect on the expected recovery by the

\footnotetext{
${ }^{9}$ See 42 U.S.C. § 9613(f)(2) (2000). Klerman (1996) refers to such a setoff rule as an "unconditional" pro tanto setoff rule, because the court applies this setoff without inquiring into whether the settling defendants were actually liable.

${ }^{10}$ CERCLA protects a settling PRP from contribution actions brought by other PRPs. See 42 U.S.C. § 9613(f)(2) (2000).
} 
government, as each defendant would settle or pay a judgment for an amount related to only its equitable share.

\section{B. The Brownfields Problem}

Superfund liability may well inhibit the development of contaminated property by discouraging buyers from purchasing these sites, but the reasons for such an effect are more subtle than they might first appear. After all, if the liability rules merely forced the buyer to accept some share of a fixed expected liability that they would otherwise impose on the seller, then they would not deter a developer from buying the property as long as that transaction would efficiently transfer the property to the party that would produce greater value from the property. The parties would simply adjust the price of the property downward to reflect the transfer of liability from seller to buyer, and this discount would ensure that economically efficient transactions go forward in spite of this transfer of liability. The previous economic literature, however, identifies some possible reasons that a transfer of liability to a party buying contaminated property may nevertheless discourage efficient transactions.

First, Segerson (1993) notes that if the buyer and the seller are not equally likely to be judgment-proof, then a transfer of liability would distort incentives to transfer the property from buyer to seller. Liability would create too great an incentive to transfer the property to prospective buyers that are more likely to be judgment-proof than the current owner and too little incentive to transfer the property to prospective buyers that are less likely to be judgment-proof than the current owner. Second, Boyd, Harrington, and Macauley (1996, p. 47) note that if the seller is better informed than the buyer about the environmental condition of the property, then this information asymmetry can create an adverse selection problem that drives high-quality property from the market. Third, they also note that even if the buyer and seller are equally well informed, the government's ability to detect contaminated sites is imperfect, and current owners may keep property off the market to avoid attracting the attention of regulators to contamination at the site (Boyd, Harrington \& Macauley, 1996, pp. 49-52).

Chang and Sigman (2007) identify additional reasons that Superfund liability could discourage efficient transactions. Superfund liability may have these effects even if the buyer and seller are equally likely to be judgment-

proof and have the same information regarding contamination at the site and even if the transaction has no effect on the probability of detection by 


\section{COST RECOVERY IN SUPERFUND CASES}

regulators. All of the barriers to efficient transactions identified by Chang and Sigman (2007) flow from the following feature of Superfund liability: If a PRP that owned the site "at the time of disposal of any hazardous substance" sells the property, then under CERCLA, after such a sale, both the buyer and the seller are PRPs. ${ }^{11}$ That is, the number of PRPs that the government can hold jointly and severally liable increases upon such a sale if the buyer was not already a PRP. Furthermore, the law defines "disposal" broadly to include "the discharge, deposit, injection, dumping, spilling, leaking, or placing of any solid waste or hazardous waste into or on any land or water."12 Given this broad definition of "disposal," some courts have held prior owners liable even if they engaged in no active disposal themselves if they owned the land while wastes previously deposited on the land continued to leak or spill during their ownership. $^{13}$ The broader the definition of "disposal," the more likely courts are to hold prior owners liable as PRPs, and the more likely each sale of the property is to increase the number of PRPs.

Chang and Sigman (2007) use a formal model of joint and several liability developed earlier by Chang and Sigman (2000) to generate predictions of the effects of Superfund liability. Chang and Sigman (2000) tested predictions about the probability and speed of settlement in an empirical analysis of Superfund cases but did not study the effects of this liability regime on the amounts recovered by the government. The same model also allows us to study the effects of sales of contaminated property on the amount recovered by the plaintiff, however, because this model allows us to vary the number of PRPs at a contaminated site. This model extended the models of joint and several liability developed earlier by Kornhauser and Revesz (1994) and Polinsky and Shavell (1981), which assumed only two defendants, and by

\footnotetext{
${ }^{11} 42$ U.S.C. § 9607(a)(2) (2000).

12 Solid Waste Disposal Act § 1004, 42 U.S.C.§ 6903(3) (2000); see CERCLA, 42 U.S.C. $\S 9601(29)$ (2000) (incorporating the definition from the Solid Waste Disposal Act § 1004 into CERCLA).

${ }^{13}$ See, e.g., Nurad, Inc. v. William E. Hooper \& Sons, 966 F.2d 837, 844-46 (4 ${ }^{\text {th }}$ Cir. 1992), cert. denied, 506 U.S. 940 (1992); Carson Harbor Village, Ltd. v. Unocal Corp., 270 F.3d 863, 879-81 ( $9^{\text {th }}$ Cir. 2001), cert. denied, 535 U.S. 971 (2002). But see United States v. 150 Acres of Land, 204 F.3d 698, 705-06 ( $6^{\text {th }}$ Cir. 2000); ABB Industrial Sys. v. Prime Tech., Inc., 120 F.3d 351, 357-59 (2d Cir. 1997); United States v. CDMG Realty Co., 96 F.3d 706, 713-18 (3d Cir. 1996) (same).
} 


\section{HOWARD F. CHANG and HILARY SIGMAN}

Easterbrook, Landes, and Posner (1980, pp. 356-60), which assumed perfect correlation in outcomes at trial among all defendants and costless litigation.

Chang and Sigman (2007) predict that an increase in the number of PRPs would have four distinct effects that would each discourage sales of contaminated property. First, if a sale of the property increases the number of available defendants by adding the buyer as a new PRP, then the expected liability of the buyer and the seller taken together increases insofar as the addition of a new PRP tends to shift the allocation of expected liability away from PRPs other than the buyer and the seller. ${ }^{14}$ Second, as long as the outcome at trial for the buyer is not perfectly correlated with the outcome at trial for any other PRP, then a sale would increase the amount of damages that the government can expect to recover from the PRPs at trial and would increase the expected liability of the buyer and the seller taken together. This effect is an extension of the effect noted by Kornhauser and Revesz (1995, pp. 138-39) in the case of only two defendants, insofar as the expected recovery of the government under joint and several liability continues to increase as the number of defendants increases. Third, a sale would tend to increase the collective litigation costs of the buyer and the seller taken together. Fourth, a sale may increase the amount that the government can expect to extract from PRPs in a settlement.

The improvement in the government's bargaining position in settlement negotiations derives in part from the second and third effects noted by Chang and Sigman (2007). When a sale increases the amount that the government can expect to recover at trial and the total litigation costs that a buyer and a seller face as a group, each effect shifts the threat point in settlement negotiations in favor of the government and against the buyer and seller of a brownfield site. If outcomes at trial are sufficiently correlated among defendants, however, then settlement negotiations can add yet another reason for the risk of Superfund liability to inhibit development of contaminated

\footnotetext{
${ }^{14}$ By bringing contribution actions against other PRPs, a defendant can ensure that they bear an equitable share of response costs even if the government has not filed suit against those other PRPs. Under the Uniform Contribution Among Tortfeasors Act, a defendant that has paid more than a pro rata share of a joint and several liability has a right to contribution from another defendant that has paid less. Unif. Contribution Among Tortfeasors Act $\S 1$ (b) (amended 1955), 12 U.L.A. 185, 194 (1996). Under CERCLA, however, courts "may allocate response costs among liable parties" when a private party seeks contribution from other PRPs "using such equitable factors as the court determines are appropriate." 42 U.S.C. § 9613(f)(1) (2000).
} 


\section{COST RECOVERY IN SUPERFUND CASES}

property: an increase in the number of defendants may increase the government's ability to exploit the race among the defendants to settle, as noted by Easterbrook, Landes, and Posner (1980). Furthermore, a larger number of defendants seems likely to reduce the defendants' bargaining power by making cooperation among them in settlement negotiations more difficult.

Thus, the second, third, and fourth effects distinguished by Chang and Sigman (2007) would each imply that the government would recover a larger amount as the number of PRPs increases. Chang and Sigman (2007) predict that the second and fourth effects would be most important when the number of PRPs is small and that the amount recovered by the government would increase at a diminishing rate as the number of PRPs grows, that is, recovery should be concave in $N$, where $N$ is the number of PRPs. Empirical evidence also confirms that litigation costs increase relative to cleanup costs as the number of PRPs increases, holding other factors constant, and that this increase also appears to be the most dramatic for sites with relatively few PRPs (Acton \& Dixon, 1992, pp. 51-52, 61; Dixon, 1995, pp. 176-77; Dixon, Drezner \& Hammitt, 1993, p. 37). These data suggest that the second effect identified by Chang and Sigman (2007) would also be most important when the number of PRPs is small.

These comparative statics results are significant, given the small size of most brownfields. A recent study notes that these sites include a "large number of abandoned gas stations and garages, former dry cleaning establishments, small fabrication facilities, leaking underground storage tanks, and other facilities," and estimates that the size of the median brownfield site is probably one acre or less (Wernstedt et al., 2004, p. 8). For most of these sites, an owner contemplating a sale would anticipate that there would be very few other PRPs available as defendants in a potential lawsuit to recover cleanup costs.

The first, third, and fourth effects distinguished by Chang and Sigman (2007) are associated with the joint and several liability imposed by Superfund, whereas the qualitative effects identified by Segerson (1993) and Boyd, Harrington, and Macauley (1996) flow more generally from the transfer of liability to new owners, whether or not this liability is joint. Sigman (2009) presents empirical evidence that joint and several liability in particular inhibits the development of contaminated sites. Those results suggest that joint and several liability reduces land prices and increases vacancy rates in central cities. This evidence of the brownfields problem is consistent with the theory presented by Chang and Sigman (2007). The empirical analysis that follows 
10

HOWARD F. CHANG and HILARY SIGMAN

provides another opportunity to search for evidence of the brownfields problem and to test for the predictions that emerge from economic theory.

\section{DATA}

To explore these relationships empirically, we study federal cost recovery actions for cleanup under the Superfund law. Under CERCLA, the EPA may seek to compel private parties to undertake cleanup or may fund cleanup from the Superfund Trust Fund and then seek to recover cleanup costs from PRPs. Although our model might apply to either funding approach, the empirical analysis focuses specifically on cost recovery actions because the amount obtained, relative to the amount sought by the government, is most easily observed in this context. Information on the dollar amount of settlements or recoveries at trial can be combined with the EPA's reported spending at the site to produce a good measure of the share of costs recovered. By contrast, when the PRPs agree in a settlement to conduct a privately funded cleanup, no public database records the amount that the government would have liked the PRPs to spend. Furthermore, whether this amount is high or low will depend on characteristics of the site, and much of this heterogeneity among sites is difficult to observe.

We assemble a data set on the value of cost recoveries obtained by the federal government at Superfund sites, whether these amounts are won at trial (about 2.5\% of sites) or negotiated in settlements. ${ }^{15}$ This section describes the sources of data and the resulting data set for our analysis. We first discuss our data for the dependent variable in our analysis, then we discuss our data for the explanatory variables.

\footnotetext{
${ }^{15}$ The difference between cost recoveries at sites with some disputes resolved at trial and those at sites without any trial outcomes was not statistically significant. Thus, we do not distinguish amounts awarded at trial from those obtained through settlements in the analysis that follows.
} 


\section{COST RECOVERY IN SUPERFUND CASES}

\section{A. The Dependent Variable}

Our basic data source on disputes is the EPA's Integrated Compliance Information System (ICIS), which contains records of civil, judicial, and administrative federal EPA enforcement cases. Our data set contains information on cases filed through April 2009. We restrict the data to cases listing CERCLA as the relevant statute.

The EPA provided us with an extract from its accounting database, the Integrated Financial Management System (IFMS) for CERCLA spending, which allows us to estimate the ratio between total costs recovered at a site and federal spending at the site. Although the extract disaggregates spending for different events, it does not have dates for these events, so our spending data are undiscounted totals for nominal outlays rather than real present values. These data were merged with the enforcement data (using some intermediate EPA site codes).

A small number of cases have recoveries that are several times the reported expenditures. We suspect that the administrative spending data, especially the older data, may sometimes be incomplete, which would produce some measurement error in our dependent variable. This measurement error, however, does not seem to be systematically related to our variables of interest. Furthermore, values greater than one may be valid, because the recovery at a site may include overhead and interest, which we cannot calculate because we do not know the timing of expenditures. To exclude those observations most likely to reflect measurement error, we restrict our sample to sites with a cost recovery no greater than three times the costs, which includes about $90 \%$ of sites in the data. Our main results regarding the effects of increasing $N$ and other covariates are robust to more or less restrictive caps on plausible cost recovery shares, although estimates for mean recovery are sensitive to these caps.

Table 1 reports summary statistics for the sites in our data set. Our primary data set only includes sites with at least one case in the enforcement data. The mean cost recovery at sites with cases was $\$ 1.98$ million. The mean cost to the government was $\$ 5.51$ million, but the distribution is skewed by a few sites with very high costs. The median cost was $\$ 851,000$. The mean site yielded recovery of $56.1 \%$ of reported costs.

Table 1 also reports the data for a larger group of sites that have positive reported government expenditure, but may not have any cases reported in the enforcement data. Sites may be absent from the enforcement data because the 


\section{HOWARD F. CHANG and HILARY SIGMAN}

government has chosen not to pursue cost recovery or has not yet begun formal proceedings to recover costs. Some sites may be in this group as a result of incomplete data: the enforcement data seem to have significant omissions, especially before the most recent decade. We assume that recovery at these "no case" sites is zero. Because this assumption may not be valid for some sites, we prefer the smaller data set for our analyses, but we report results with the broader data as a sensitivity check.

\section{B. Explanatory Variables}

Explanatory variables derive from a few data sets that we merged with the cost recovery and administrative spending data. One prediction from the prior literature that we especially wish to test concerns the amount of cost recovery as a function of the number of PRPs. Let $N$ denote this number. We have two alternative measures of $N$. One measure of $N$ is a count of the number of defendants at each Superfund site in the ICIS enforcement data. Our second measure of $N$ comes from the Site Enforcement Tracking System (SETS), which provides names and addresses of PRPs that have been sent notice letters. Each measure has its advantages and disadvantages.

The defendant counts may more accurately reflect the number of viable defendants, for example, screening out judgment-proof PRPs sent notice letters but not pursued. This measure would be more relevant for testing the predictions generated by the model in Chang and Sigman (2007), which arise even if all PRPs are solvent. Furthermore, the list of notice letters appears to be incomplete as a list of PRPs, insofar as it fails to include all the defendants listed in Superfund law suits.

On the other hand, the notice letter data generally represents a more complete list of all potentially liable parties. If the EPA recovers all its costs from one group of PRPs, for example, then other PRPs may never appear as defendants. Yet we may want to include all those PRPs in our measure of $N$, for example, if we want to include the effect generated by the model in Segerson (1994), which requires at least some PRPs to be judgment-proof. The PRP count data are available for the broader group of sites that may have had no reported case, and we report and use these data in that context. The correlation between the two measures of $N$ is high (.57), however, so in practice the regression results are qualitatively similar with either measure.

Table 1 reports that the mean number of defendants at a site was 17.6 and the mean number of PRPs at a site was 26.7, but the distribution is very 


\section{COST RECOVERY IN SUPERFUND CASES}

skewed, and most sites had considerably fewer defendants and PRPs. The median number of defendants was 3 , and the median number of PRPs was also 3 in the larger data set. As the table reports, $29 \%$ of the sites in the data have only one defendant or only one notified PRP. These $N=1$ sites provide examples of Superfund cases without any of the effects of joint and several liability.

Another explanatory variable is the degree of correlation among defendants in outcomes at trial, which the prior literature predicts would reduce the expected cost recovery under joint and several liability. As outcomes at trial become more independent, theory predicts that the average cost recovery should increase. To measure the correlation in outcomes at trial, we focus on PRP characteristics that may lead PRPs at a site to pursue different defense strategies. We expect sites with defendants pursuing diverse legal defenses to exhibit less positive correlation among defendants in trial outcomes.

Our first measure of such diversity is whether the PRPs at the site include off-site waste generators and transporters in addition to past and present owners and operators of the site. Off-site PRPs may raise legal defenses that differ from those raised by on-site PRPs. Whereas off-site PRPs may be more likely to deny involvement with the site, for example, site owners may invoke a defense for "innocent purchasers" of the site (Percival et al., 2003, p. 236), a defense not available to waste generators or transporters. ${ }^{16}$ Uncertainty over a court's receptivity to each of these legal defenses may imply some positive correlation in trial outcomes among PRPs invoking the same type of defense and less correlation in trial outcomes among PRPs offering different defenses. Thus, the presence of off-site PRPs at the site may reduce correlation among defendants in trial outcomes.

Data on whether sites have off-site contributors among their PRPs derive from a 1993 survey of Remedial Project Managers (RPMs), the officials in charge of overseeing cleanup at each site on the National Priorities List (NPL). ${ }^{17}$ The RPM data set pertains only to sites that were on the NPL in 1993, whereas our other data sources include sites that are not on the NPL but addressed by federal removal actions and sites added to the NPL since 1993.

\footnotetext{
${ }^{16}$ See 42 U.S.C. § 9601(35)(A)(i), (B) (2000).

${ }^{17}$ See U.S. Environmental Protection Agency (1995). The EPA may conduct "removal” operations to address "an imminent and substantial danger to the public health" or "the environment,” 42 U.S.C. § 9604(a)(1) (2000), but may conduct longer-term remediation operations only at sites on the NPL (see id. § 9605; Percival et al., 2003, p. 224).
} 


\section{HOWARD F. CHANG and HILARY SIGMAN}

Thus, only a subset of the sites in the main data set are in the RPM data, and sample sizes for equations containing variables from the RPM data are much smaller.

Our second variable expected to affect the correlation among defendants in trial outcomes is whether some contamination occurred at the site after 1980. Virtually all NPL sites had some contamination prior to 1980, the year that Congress passed the Superfund law, but only some of these sites had additional contamination after 1980 (U.S. Environmental Protection Agency, 1995). If the same PRPs contributed to both the earlier contamination and the later contamination, then we would not expect contamination in both periods to affect the correlation among defendants in trial outcomes. If different defendants contributed contamination at different times, however, then the difference in timing may cause defendants to offer different legal defenses.

In particular, because the Resource Conservation and Recovery Act (RCRA) ${ }^{18}$ imposed requirements for "cradle to grave" tracking of hazardous waste in the late 1970s, the sources of contamination are probably better documented in the later period than the early period. A defendant associated with earlier contamination would therefore be more likely to deny contributing waste to the site, raising a defense likely to turn on evidence specific to that individual defendant. A defendant associated with later contamination may be more likely to raise legal defenses less dependent on defendant-specific factual findings. These defenses may be more likely to turn on legal issues raised by other defendants. The more important these common legal defenses become, the greater the correlation among defendants in trial outcomes may become. If so, contamination from the later period may increase the correlation among defendants in trial outcomes.

It is also possible, however, for more recent contamination to reduce this correlation. Trial outcomes for defendants that deny contributing waste to the site may be correlated insofar as there may be uncertainty regarding how receptive the court would be to such claims in general. Trial outcomes for defendants raising other legal defenses may be independent if each defendant would raise a different and unrelated defense. In any event, we include this control variable to capture the net effect of contamination after 1980 on cost recovery, whether this effect proves to be negative or positive on balance.

Furthermore, because litigation costs may affect settlement negotiations, we would also like measures of the variation in these costs for the plaintiff and

${ }^{18} 42$ U.S.C. §§ 6901-6992k (2000). 


\section{COST RECOVERY IN SUPERFUND CASES}

the defendants. Because the plaintiff is the same in all federal Superfund cases, measures of variation in the plaintiff's costs are not obvious. Heterogeneity across defendants, however, may correlate with defendants' litigation costs. We consider two different defendant characteristics that we can derive from the list of defendants' names. We include both as control variables to see how robust our results are with respect to the effect of $N$.

First, we coded defendants as either firms or other types of defendants. Non-firm defendants include individuals and their estates, local governments, federal agencies, and nonprofit organizations, including universities. Firms may have systematically higher or lower litigation costs because they are the least likely to indulge tastes regarding legal disputes, either for or against litigation. ${ }^{19}$ Furthermore, if firms tend to have deeper pockets than individuals or other non-firm defendants, then the presence of firms as defendants may increase cost recovery because firms are less likely to be judgment-proof.

Second, we identified defendants at each site that were also defendants at other sites. Table 1 reports that on average $25.9 \%$ of defendants at a site were also defendants for at least one other site, suggesting that these repeat players are very important in practice. The number of sites at which a defendant is a PRP may have several possible effects on settlement negotiations.

On the one hand, these defendants may reduce settlement amounts for two reasons. Defendants who are PRPs at multiple sites may develop more expertise and enjoy some economies of scale, tending to decrease their litigation costs and to improve their bargaining power in settlement negotiations. In addition, these defendants may have the incentive to establish reputations for driving a hard bargain, reducing their aversion to litigation and thus also tending to produce lower settlement offers.

On the other hand, PRPs that are present at multiple sites may increase settlement offers if such PRPs face higher costs in terms of public relations when they appear to thwart cleanup at a site. These PRPs may also agree to higher settlement amounts because the government can threaten retaliation against them at other sites if they are uncooperative. Furthermore, defendants with more litigation experience may have a more realistic sense of their chances of success, making it less likely that an optimistic bias will induce lower settlement offers. Finally, because these defendants tend to be larger

\footnotetext{
${ }^{19}$ Eisenberg and Farber (1997) argue that market discipline will force firms to indulge either taste less freely than other litigants.
} 


\section{HOWARD F. CHANG and HILARY SIGMAN}

entities, they may also have deeper pockets than other defendants and therefore yield greater cost recovery.

In general, we would also expect litigation costs to have a smaller effect on the share of cleanup costs recovered by the government as cleanup becomes more costly in absolute terms. Empirical evidence suggests that litigation costs are likely to be larger relative to cleanup costs for sites where remedies are less costly. Data collected by RAND show that at sites with relatively low cleanup costs, litigation costs accounted for a larger share of expenditures than at those with higher cleanup costs, other factors held constant (Dixon, 1995, p. 177; Dixon, Drezner \& Hammitt, 1993, p. 37). Thus, for example, insofar as litigation costs confer an advantage to the government in settlement negotiations, this advantage would have a less important effect on the share of cleanup costs recovered as those cleanup costs grow larger in absolute terms. This effect might lead one to expect the share recovered to decrease as cleanup costs increase.

Furthermore, PRPs may be less likely to be able to pay the full costs of cleanup as those costs grow larger, which may also lead us to expect the share recovered to fall as those costs rise. On the other hand, if the government's threat to sue becomes more credible as the amount at stake increases relative to litigation costs, then we might expect the share recovered to increase as cleanup costs increase. To capture all of these possible effects, we include the absolute cost of cleanup by the federal government as a control variable.

Finally, holding the government's bargaining power constant, we might also expect the share of government cleanup costs recovered to vary inversely with the need to get PRPs to fund additional cleanup. The government might face a tradeoff between recovering its own cleanup costs from the PRPs and extracting other concessions in the form of privately funded cleanup. We use two alternative measures of direct PRP expenditures to control for this heterogeneity among sites.

First, the ICIS enforcement data includes the cost to defendants of privately funded cleanup mandated by the government. The quality of these data, however, seems poor. In particular, the share of cases with positive costs reported is considerably smaller than the share of sites known to have privately funded cleanups. We suspect that the data set often reports zero cost when the true value is unknown or not specified in the settlement. Furthermore, like the share of government cleanup costs recovered, the cost of mandated private cleanup is likely to be an endogenous function of the bargaining power of the government, which makes this variable less than ideal as an explanatory variable. Nevertheless, we consider it useful to include this cost as a control 


\section{COST RECOVERY IN SUPERFUND CASES}

variable simply to test whether our results are robust for the explanatory variables of primary interest.

Second, the 1993 RPM survey asked site managers to estimate past and future PRP expenditures at their sites. The managers chose one of ten possible ranges to represent the total amount at each site. We use the mid-point of each range to construct a single summary variable for estimated PRP expenditures. For example, the median response for estimated PRP expenditures was in the range of $\$ 10$ million to $\$ 15$ million in our data set. As indicated in Table 1, we use the mid-point value, $\$ 12.5$ million, as the cost for the median site.

\section{RESULTS}

Table 2 contains our most basic comparison between nonjoint and joint liability, comparing sites with $N=1$ to sites with higher numbers of defendants or PRPs. As Table 2 reports, sites with one defendant have an average recovery of 32\%, whereas those with more than one have an average recovery more than twice as large, 66\%. Similarly, if we examine all sites (with "no case" sites treated as having zero recovery) and use the number of PRPs for $N$, the average recovery is $17.4 \%$ for single PRP sites and $37.9 \%$ for multi-PRP sites. For each definition of $N$, a t-test strongly rejects the hypothesis that the sites subject to joint liability and those subject to nonjoint liability have the same mean for the share of costs recovered.

Table 3 explores the relationship between cost recovery and $N$ in more detail, examining in particular the hypothesis that cost recovery is concave in $N$. Column (1) defines $N$ as the number of defendants, whereas column (2) defines $N$ as the number of PRPs sent notice letters. In each case, we run a linear regression ${ }^{20}$ using a different dummy variable for each size class with $N>1$. We define the classes finely for small $N$, despite some loss of precision in the estimated coefficients due to small cell sizes, because the brownfields

\footnotetext{
${ }^{20}$ The dependent variable is zero for many observations, so we might use a censored model such as a Tobit. Estimates using a Tobit yielded similar estimates for marginal effects as the linear models presented here, but a test of conditional means rejects the Tobit specification. The Ordinary Least Squares (OLS) coefficients provide a reasonable estimate of the marginal effects of interest (those for the realized recoveries, including observations where the recovery equals zero) without making the restrictive assumptions required for the Tobit (Cameron and Trivedi, 2005, p. 542).
} 


\section{HOWARD F. CHANG and HILARY SIGMAN}

problem makes us especially interested in the effects observed at sites with small $N$.

The results in Table 3 are consistent with the hypothesis that cost recovery is concave in $N$, with either of our two definitions of $N$. In column (1), the government recovers a share of costs at sites with two defendants that is 10.6 percentage points greater in expectation than the share of costs recovered at single-defendant sites. Recovery at sites with three to four defendants is 19.5 percentage points greater than recovery at single-defendant sites, and the estimated function becomes much flatter thereafter. The effects are similar when we use the PRP notice letters in column (2). The increase in the number of PRPs from one to two yields an increase of 7.4 percentage points in cost recovery, with little difference in the increase for three to four defendants. The function is flatter for PRP notices than for defendants, presumably because some of the recipients of notice letters are judgment-proof.

Figure 1 shows estimates of a flexible functional form for the relationship between the share recovered and the number of defendants. The figure is the predicted value and confidence interval for a regression of share recovered on two powers of defendant count, where the estimation procedure has selected the powers that yield the best fit. ${ }^{21}$ We restrict the data set to sites with fewer than 50 defendants, so the estimates are not unduly influenced by the small number of sites that have vast numbers of defendants and are not the focus of our interest. The flexible functional form is consistent with many different shapes, but the estimated shape appears to be concave over the region of interest. The results are also consistent with a monotonically increasing function of the number of defendants. The confidence interval widens as the number of defendants increases, probably because the number of observations tends to fall as we move toward sites with larger number of defendants.

In Table 4, we examine the effects of the other determinants of cost recovery amounts. These specifications also allow us to examine whether our results for $N$ are robust when we control for these other factors. Table 4 reports our results using the number of defendants as our measure of $N$. The inclusion of other factors in columns (1), (2), (3), and (4) does not change our results regarding the effect of $N$ on cost recovery. Cost recovery still increases

\footnotetext{
${ }^{21}$ The estimator considered the powers $-2,-1,-.5, .5,1,2,3$, and the log of defendant count and found that the powers .5 and 1 of defendant count yielded the best fit. The estimated coefficients (and standard errors) were 1.065 (.182) and -.295 (.089) on these powers of defendant count, respectively. The estimated increase in share recovered when the number of defendants increases from one to two is 14.6 percentage points.
} 


\section{COST RECOVERY IN SUPERFUND CASES}

in $N$, and the function becomes flatter as $N$ grows larger, as predicted by the prior literature. If anything, the estimated effect of $N$ at sites with small numbers of defendants is even greater once we control for other factors.

Column (1) includes the characteristics of the defendants, specifically the fraction of defendants at the site that are firms and the fraction of defendants at the site that are also defendants at multiple sites. Increasing the fraction that are repeat defendants has a statistically significant positive effect on the share of cost recovered. These repeat defendants may agree to higher settlement amounts, for example, because they have higher effective litigation costs, less biased perceptions of their prospects for success, or deeper pockets. The share of defendants that are firms also has a significant positive effect on cost recovery. This coefficient may reflect either higher effective litigation costs or deeper pockets for firms than for other defendants.

Column (2) in Table 4 adds the federal government's cost of cleanup as another explanatory variable. This cost has a statistically significant negative effect on the share of costs recovered. Larger cleanup costs may be associated with lower recovery because litigation costs become relatively less important as a source of bargaining power for the government. This result may also emerge because the PRPs are less likely to be able to pay the full costs of cleanup as those costs become larger. Finally, the negative correlation between this explanatory variable and the dependent variable may simply reflect errors in the measurement of the federal government's cost of cleanup. In any event, all the coefficients maintain the statistical significance that they exhibit in column (1) when we add this new explanatory variable in column (2), and each coefficient increases in absolute value as we go from column (1) to column (2).

Column (3) in Table 4 adds the cost of privately funded cleanup mandated by the government as a control variable. This cost has a statistically negative effect on the share of costs recovered. Thus, once we control for the sources of bargaining power reflected in the other explanatory variables, the government does seem to recover less of its own cleanup costs when it extracts greater concessions in the form of privately funded cleanup. Most important, all of our other coefficients in column (3) maintain the statistical significance that they displayed in column (2), and all but one maintains or increases its absolute value.

Column (4) in Table 4 adds explanatory variables from the survey of Remedial Program Managers to the analysis in column (2): we introduce a dummy variable for the presence of an off-site PRP, a dummy variable for contamination at the site since 1980, and a variable for the estimated cost of 


\section{HOWARD F. CHANG and HILARY SIGMAN}

PRP expenditures at the site. We expect the first two of these added variables to affect the correlation among defendants in trial outcomes. Although the inclusion of these explanatory variables reduces the number of observations, all but one of the coefficients repeated from columns (1) and (2) remain significant at the 5\% level in column (4). The other coefficient remains significant at the $10 \%$ level and increases in absolute value. Thus, our primary results prove to be quite robust when we control for several other important sources of heterogeneity among sites.

We find a positive and statistically significant coefficient on the dummy variable for the presence of off-site defendants. Because we control for the number of defendants, we interpret the presence of off-site PRPs as suggesting a lower correlation among defendants in trial outcomes. The result here is thus consistent with the prediction that such a reduced correlation would increase the amount of cost recovered by the government under joint and several liability.

The coefficient for the dummy variable for recent contamination, the second factor we expect to affect the correlation among defendants in trial outcomes, has a negative point estimate. This sign is consistent with the hypothesis that defendants contributing contamination since 1980 are more likely to raise legal defenses that imply greater correlation in trial outcomes than defendants contributing less recent contamination. This result, however, is not statistically significant.

The coefficient on site manager's estimate of PRP expenditures at the site is negative and statistically significant. ${ }^{22}$ This result appears to confirm the evidence of substitution between direct expenditures by PRPs and cost recovery observed in column (3). The estimated effect, however, is small: increasing PRP direct expenditures by one standard deviation (\$28.4 million) reduces the share of costs recovered by the government by only 6 percentage points (or $\$ 300,000$ at mean government costs).

Finally, column (5) in Table 4 restricts the data to sites that the site managers report have no off-site PRPs. We impose this restriction because the

\footnotetext{
${ }^{22}$ Analyses that used a set of dummy variables for the estimated expenditure ranges (instead of a single continuous variable) produced very similar coefficient estimates for the other variables in our equations. We report results for the continuous variable for ease of interpretation. A substantial number of the survey responses are missing. To keep the data for these sites in our analysis, we include a dummy variable to indicate these missing survey responses and set the continuous variable equal to zero at those sites. The missing value dummy is not statistically different from zero in the estimated equation.
} 


\section{COST RECOVERY IN SUPERFUND CASES}

effect of an increase in the number of owners or operators at a site is especially relevant for the brownfields problem. The brownfields problem predicted by Chang and Sigman (2007) arises when a sale or lease of a contaminated site brings in a new owner or operator and thus adds another PRP to the site. The specification in column (5) allows us to test whether the effects of $N$ reported in Table 3 continue to hold in this special case. The results in column (5) suggest that those results do indeed emerge in this more restricted data set. Cost recovery seems to maintain about the same relationship with $N$ (for $N<100$ ) as in Table 3 , although the coefficient estimates are less precise perhaps because of the much smaller number of observations. ${ }^{23}$ Thus, the data for owners and operators seem to be consistent with the effects of $N$ predicted by Chang and Sigman (2007).

\section{DisCUSSION}

Our results indicate that increasing the number of PRPs or defendants greatly increases the expected liability of PRPs at Superfund sites. Column (1) in Table 3, for example, suggests that increasing the number of defendants from one to two raises the government's expected recovery from $32 \%$ of its costs to $43 \%$. The magnitude of this implicit tax on sales or lease transactions suggests a substantial deterrent for an owner contemplating either a sale to a new owner or a lease to a new operator. In either case, this implicit tax may discourage an efficient transaction and thus generate a brownfields problem. Our results are all the more striking given that they seem likely to understate the deterrent effect of the number of PRPs on the sale or lease of most brownfields for several reasons.

First, our data include only the recovery of costs incurred by the government. A larger number of defendants may also improve the government's ability to extract concessions from the defendants in settlement negotiations in the form of privately funded cleanup. The available data on the cost of privately funded cleanups indicate it also increases as the number of defendants or PRPs at a site increases in our sample; this cost is also positively correlated with the amount recovered from defendants for

\footnotetext{
${ }^{23}$ The coefficients on the size classes of $N$ do rise dramatically at the upper end of the range, but this area $(N>100)$ is less relevant for most brownfields. Furthermore, the data quality is suspect in this range. It seems implausible that sites with only owner and operator PRPs would have a very large number of PRPs. Most such sites have only a small number of PRPs.
} 


\section{HOWARD F. CHANG and HILARY SIGMAN}

government cleanup. ${ }^{24}$ Thus, the evidence is consistent with the hypotheses that the government's ability to extract costly concessions increases with the number of defendants or PRPs and that the government uses its bargaining power both to recover more of its own cleanup costs and to require the defendants to spend more on privately funded cleanups. Furthermore, there is no evidence that the government shifts from extracting one type of concession to extracting the other as the number of defendants or PRPs increases ${ }^{25}$ which suggests that our results would also apply to the cost of privately funded cleanup as a function of the number of defendants or PRPs. The costs of privately funded cleanup could deter the sale of brownfields, just as greater expected liability for publicly funded cleanup would.

Second, sale of a site could shift expected liability from other defendants to the buyer and the seller of the site. Third, a larger number of defendants may also increase the litigation costs that the defendants bear, either by litigating to judgment at trial or prior to negotiating a settlement. These litigation costs are quite large relative to cleanup costs. A 1994 RAND study of Superfund sites estimated that such costs accounted for 32 percent of private-sector PRP expenditures through 1991, with cleanup costs accounting for the other 68 percent (Dixon, 1995, pp. 179, 183). That is, these litigation costs were equal to nearly half of the cost of cleanup itself. Either transfers to other defendants or increased litigation costs could deter sales, just as increased recovery by the government of its cleanup costs could.

Furthermore, we suspect that the federal cases in our sample involve especially large cleanup costs, and empirical evidence suggests that litigation costs are even larger relative to cleanup costs at sites with lower cleanup costs, holding other factors constant (Dixon, 1995, p. 177; Dixon, Drezner \& Hammitt, 1993, p. 37). The median brownfield site is small and likely to have cleanup costs that are low compared to the sites studied by RAND, even if these costs are large compared to the value of the property. These facts suggest that the share of expenditures that owners expect to devote to litigation

\footnotetext{
${ }^{24}$ This cost is positively correlated with both the number of defendants and the number of PRPs (correlation coefficients of .08 and .07, respectively) and with cost recovery (correlation coefficients of .11 overall or .36 if we condition on positive values for both cost recovery and private cleanup costs).

${ }^{25}$ To be more precise, neither the number of defendants nor the number of PRPs has a statistically significant effect on the ratio between cost recovery and the sum of the cost of mandated private cleanup and cost recovery.
} 


\section{COST RECOVERY IN SUPERFUND CASES}

costs at most brownfields are even higher than suggested by the RAND estimates, which were based on sites on the National Priorities List, and higher than those at sites appearing in our sample of federal cases. Thus, the impact of the litigation costs added by the sale of a site is likely to be greater at most brownfield sites than at the sites in our sample.

Thus, litigation costs in our sample are likely to have a relatively small effect on the share of cleanup costs recovered by the government, compared to the typical brownfields site. We find evidence that as cleanup costs grow larger, the government recovers a smaller share of these costs. This result is consistent with the hypothesis that litigation costs are a source of bargaining power for the government that is most important when the cost of cleanup is relatively small, which is likely to be especially true of the typical brownfields site.

Finally, the threat of liability is most likely to deter sales precisely when that threat imposes the greatest cost. If potential PRPs avoid transactions that would connect them with those particular sites, then we will be unable to observe the large increases in the government's recovery that would occur if the number of PRPs at those sites were to increase. This selection effect will tend to leave only sites with relatively small costs caused by increases in the number of PRPs in our sample, which will cause our results to underestimate the effect of a sale of the average site.

On the other hand, there is also a selection effect that may tend to produce a bias in the opposite direction. If potential PRPs avoid transactions that would connect them with sites that feature judgment-proof PRPs, because any new PRP would bear a larger share of any expected liability at those sites, then these sites may be more likely to have few PRPs. Insofar as the presence of judgment-proof PRPs would also tend to reduce the government's recovery of its cleanup costs, this selection effect would tend to imply lower recovery at sites with few PRPs, which might lead us to overestimate the effect of an increase in the number of PRPs on the government's recovery at the average site.

Our results, however, suggest that this selection effect has relatively little impact on our estimates. If our estimates were an artifact of the presence of judgment-proof PRPs at some sites, then one would expect the effect that we observe to become smaller or to vanish when we remove those PRPs from our measure of $N$. Thus, if the government tends to pursue solvent PRPs rather than judgment-proof PRPs as defendants, then any upward bias in our estimates caused by judgment-proof PRPs would fall as we move from the number of PRPs to the number of defendants as our explanatory variable. If 


\section{HOWARD F. CHANG and HILARY SIGMAN}

we compare the two columns in Table 3, however, we see that our coefficients get larger rather than smaller as we move from column (2) to column (1). These results suggest that judgment-proof PRPs are not so concentrated at sites with few PRPs as to produce a substantial upward bias in our estimates.

Furthermore, when we add explanatory variables expected to be correlated with deep pockets or the judgment proof problem in columns (1) and (2) of Table 4, our results for the effect of $N$ remain virtually unchanged. If judgment-proof PRPs caused an important upward bias in our estimates, we would expect these estimates to fall when we add these explanatory variables. If anything, however, these estimates seem to increase as we add these control variables rather than decrease.

We infer that any effect of judgment-proof PRPs as a source of upward bias in our estimates is probably modest. On balance, we believe that our results are more likely to understate the deterrent effect of increases in $N$ at the average brownfields site than to overstate that effect. We are especially confident in this belief when we rely on the number of defendants rather than the number of PRPs as our explanatory variable, because our results using the number of defendants should be less subject to the effects of judgment-proof PRPs.

\section{CONCLUSION}

Our empirical results are consistent with the predictions that emerge from theoretical models of joint and several liability in the existing literature. We find that the share of cleanup costs recovered by the government is increasing but concave in either the number of defendants or the number of PRPs, as the models predict. We also find some evidence that sites with defendants with less correlated outcomes at trial may yield greater recovery of cleanup costs for the government.

Of particular policy interest, we find strong evidence that increasing the number of defendants also increases the recovery of the government's cleanup costs. Chang and Sigman (2007) suggest that such an effect may arise from joint and several liability and this implicit tax on transactions that add another PRP to the site may discourage sales of sites with known or suspected contamination, thereby contributing to the brownfields problem. Although the results may thus indicate a disadvantage of joint and several liability, it is possible that some portion of the effect that we detect would persist even in the absence of joint and several liability. After all, a larger number of defendants 


\section{COST RECOVERY IN SUPERFUND CASES}

would imply that the insolvency of any defendant is less likely to limit the government's recovery of cleanup costs, even under nonjoint liability, because the share of cleanup costs paid by each defendant is less likely to exhaust that defendant's available assets.

Whether or not the source of the effect is joint and several liability, the magnitude of the increase in cost recovery suggests a substantial implicit tax on brownfields transactions and thus lends support to efforts to keep sales of contaminated sites from increasing the number of parties subject to Superfund liability. These efforts include, for example, actions by the EPA, Congress, and the states to protect purchasers from Superfund liability. If a buyer knows for certain that it would not be treated as a PRP, for example, then the deterrent effect that we identify would be absent. Thus, by reducing or eliminating the probability that a purchaser would be liable, these policies avoid or mitigate the deleterious effects that the threat of Superfund liability can have on the incentives to buy contaminated property. Our results also suggest that the buyer has a better case for relief from liability when the number of PRPs at the site is small.

The effects that relate to brownfields, however, are only a few of the many effects to weigh in a more comprehensive analysis of the costs and benefits of these various policy alternatives. There are many other reasons militating in favor or against these policies. For example, a broader scope for joint and several liability may affect incentives for the parties to settle out of court, thereby avoiding costly litigation (Kornhauser \& Takeda, 2007; Chang \& Sigman, 2000; Kornhauser \& Revesz, 1994).

Moreover, by increasing the government's recovery of cleanup costs, joint and several liability may have complex effects on the ex ante incentives of private parties to avoid environmental contamination (Tietenberg, 1989). On the one hand, expanding the class of parties from which the government can recover full damages may promote the internalization of negative externalities in the presence of judgment-proof PRPs, which in turn would improve the incentives to reduce contamination (Segerson, 1994, pp. 266-68). On the other hand, Kornhauser and Revesz (1995, pp. 123-28) identify some circumstances in which joint and several liability could instead reduce incentives to avoid contamination.

Others have suggested that insofar as the increase in the government's recovery derives from the ability of the government to exploit a "race to settle" among the defendants, rather than from a reduction in the impact of insolvency, settlements under joint and several liability may lead to greater deterrence than trial outcomes would, which may create too great an incentive 
to avoid contamination (Easterbrook, Landes \& Posner, 1980, p. 359; Spier, 1994, pp. 562-63). On the other hand, this effect may offset the general tendency for strict liability to deter too little in the context of joint causation of harm, where each tortfeasor bears only a share of the harm it causes at the margin (Kornhauser \& Revesz, 1995, pp. 120-21). A comprehensive normative analysis of all these issues is well beyond the scope of this article. Nevertheless, our empirical analysis contributes to a more complete picture of the effects of Superfund liability, both on the share of cleanup costs recovered by the government and on the incentives for private parties to sell or lease contaminated property. 


\section{COST RECOVERY IN SUPERFUND CASES}

\section{REFERENCES}

Acton, J.P., \& Dixon, L.S. (1992). Superfund and Transaction Costs: The Experience of Insurers and Very Large Industrial Firms. RAND, Santa Monica.

Boyd, J., Harrington, W., \& Macauley, M.K. (1996). The Effects of Environmental Liability on Industrial Real Estate Development. Journal of Real Estate Finance and Economics 12, 37-58.

Cameron, A.C., \& Trivedi, P.K. (2005). Microeconometrics: Methods and Applications. Cambridge University Press, Cambridge.

Chang, H.F., \& Sigman, H. (2000). Incentives to Settle under Joint and Several Liability: An Empirical Analysis of Superfund Litigation. Journal of Legal Studies 29, 205-236.

Chang, H.F., \& Sigman, H. (2007). The Effect of Joint and Several Liability Under Superfund on Brownfields. International Review of Law and Economics 27, 363-384.

Clarke, C. (2001). Update Comparative Legal Study on Environmental Liability. European Commission, Brussels.

Dixon, L.S. (1995). The Transaction Costs Generated by Superfund's Liability Approach, in: Revesz, R.L., \& Stewart, R.B. (Eds.), Analyzing Superfund: Economics, Science, and Law. Resources for the Future, Washington, pp. 171-185.

Dixon, L.S., Drezner, D.S., \& Hammitt, J.K. (1993). Superfund: PrivateSector Expenditures and Transaction Costs. RAND, Santa Monica.

Easterbrook, F.H., Landes, W.M., \& Posner, R.A. (1980). Contribution among Antitrust Defendants: A Legal and Economic Analysis. Journal of Law and Economics 23, 331-370.

Eisenberg, T., \& Farber, H.S. (1997). The Litigious Plaintiff Hypothesis: Case Selection and Resolution. RAND Journal of Economics 28, S92-S112. 
Environmental Law Institute (2002). An Analysis of State Superfund Programs: 50-State Study, 2001 Update. Environmental Law Institute, Washington.

Geltman, E.G. (1996). Recycling Land: Encouraging the Redevelopment of Contaminated Property. Natural Resources \& Environment 10(4), 3-10.

Klerman, D. (1996). Settling Multidefendant Lawsuits: The Advantage of Conditional Setoff Rules. Journal of Legal Studies 25, 445-462.

Kornhauser, L.A., \& Revesz, R.L. (1994). Multidefendant Settlements: The Impact of Joint and Several Liability. Journal of Legal Studies 23, 41-76.

Kornhauser, L.A., \& Revesz, R.L. (1995). Evaluating the Effects of Alternative Superfund Liability Rules, in: Revesz, R.L., \& Stewart, R.B. (Eds.), Analyzing Superfund: Economics, Science, and Law. Resources for the Future, Washington, pp. 115-144.

Kornhauser, L.A., \& Takeda, K.T. (2007). N-Defendant Litigation and Settlement: The Impact of Joint and Several Liability. Law and Economics Research Paper No. 07-41. New York University, New York.

Percival, R.V., Schroeder, C.H., Miller, A.S., \& Leape, J.P. (2003). Environmental Regulation: Law, Science, and Policy, 4 ${ }^{\text {th }}$ ed. Aspen Publishers, New York.

Polinsky, A.M., \& Shavell, S. (1981). Contribution and Claim Reduction Among Antitrust Defendants: An Economic Analysis. Stanford Law Review 33, 447-71.

Segerson, K. (1993). Liability Transfers: An Economic Assessment of Buyer and Lender Liability. Journal of Environmental Economics and Management 25, S-46 to S-63.

Segerson, K. (1994). Property Transfers and Environmental Pollution: Incentive Effects of Alternative Policies. Land Economics 70, 261-272.

Sigman, H. (2009). Environmental Liability and Redevelopment of Old Industrial Land. Working Paper No. 15017. National Bureau of Economic 


\section{COST RECOVERY IN SUPERFUND CASES}

Research, Cambridge. Journal of Law and Economics 53 (forthcoming May 2010).

Spier, K.E. (1994). A Note on Joint and Several Liability: Insolvency, Settlement, and Incentives. Journal of Legal Studies 23, 559-568.

Tietenberg, T.H. (1989). Indivisible Toxic Torts: The Economics of Joint and Several Liability. Land Economics 65, 305-319.

U.S. Conference of Mayors (2003). Recycling America's Land: A National Report on Brownfields Redevelopment, Vol. 4. U.S. Conference of Mayors, Washington.

U.S. Environmental Protection Agency (1995). Users' Guide to the RPM Site Data. U.S. Environmental Protection Agency, Washington.

Wernstedt, K., Heberle, L., Alberini, A., \& Meyer, P. (2004). The Brownfields Phenomenon: Much Ado about Something or the Timing of the Shrewd? Discussion Paper No. 04-46. Resources for the Future, Washington.

Wernstedt, K., Meyer, P.B., \& Alberini, A. (2006). Attracting Private Investment to Contaminated Properties: The Value of Public Interventions. Journal of Policy Analysis and Management 25, 347-369. 
Table 1: Summary statistics

\begin{tabular}{lrrrr}
\hline \hline Variable & Mean & $\begin{array}{c}\text { Standard } \\
\text { Deviation }\end{array}$ & Median & $\begin{array}{c}\text { Number } \\
\text { of values }\end{array}$ \\
& & & & \\
\hline Conditional on a case being reported & & & & \\
Government costs recovered (million dollars) & 1.98 & 7.61 & .128 & 1522 \\
$\quad$ Share with recovery=0 & .346 & - & - & 1522 \\
Government costs (million dollars) & 5.51 & 18.7 & .851 & 1522 \\
Share of government costs recovered & .561 & .752 & .147 & 1522 \\
Defendant count & 17.6 & 60.3 & 3 & 1522 \\
$\quad$ Share sole defendant & .291 & - & - & 1522 \\
Offsite PRP present & .541 & - & - & 686 \\
Contamination since 1980 & .544 & - & - & 634 \\
Cost of mandated private cleanup (million dollars) & 6.31 & 37.5 & 0 & 1522 \\
Firm share of defendants & .684 & .350 & .8 & 1522 \\
Multi-site defendant share & .259 & .327 & .111 & 1522 \\
Estimated PRP expenditures (million dollars) & 23.2 & 28.4 & 12.5 & 503 \\
& & & & \\
Not conditional on a case & & & & \\
Government costs recovered (million dollars) & 1.20 & 6.04 & 0 & 2477 \\
$\quad$ Share with recovery=0 & .635 & - & - & 2477 \\
Government costs (million dollars) & 4.18 & 15.8 & .510 & 2477 \\
Share of costs recovered & .319 & .631 & 0 & 2477 \\
PRP count & 26.7 & 97.5 & 3 & 2477 \\
Share sole PRP & .292 & - & - & 2477 \\
\hline \hline
\end{tabular}

Notes: Standard deviation and median for continuous variables only. "Not conditional on a case" includes sites with costs, but no case reported in the enforcement data set. Cost recovery set equal to zero for sites without a case. 
Table 2: Comparison of share of costs recovered under joint and non-joint liability

\begin{tabular}{lcc}
\hline \hline & $N=1$ & $N>1$ \\
\hline$N=$ Defendants & & \\
Mean share of costs recovered & .320 & .660 \\
Standard error of mean & $(.030)$ & $(.024)$ \\
Observations & 443 & 1079 \\
\hline$N=$ Notified PRPs & & \\
Mean share of costs recovered & .174 & .379 \\
Standard error of mean & $(.018)$ & $(.016)$ \\
Observations & 724 & 1753 \\
\hline \hline
\end{tabular}


Table 3: Ordinary Least Squares estimates: Effects of $N$ with different definitions

\begin{tabular}{lcc}
\hline \hline & \multicolumn{2}{c}{ Dependent variable: Cost recovery/costs } \\
& $(1)$ & $(2)$ \\
& & \\
& & \\
& & \\
Size classes of N: & $.106^{*}$ & $.0739^{*}$ \\
2 & $(.053)$ & $(.0347)$ \\
& $.195^{* *}$ & $.0759^{*}$ \\
3 or 4 & $(.055)$ & $(.0333)$ \\
& $.337^{* *}$ & $.182^{* *}$ \\
5 to 9 & $(.058)$ & $(.0391)$ \\
& $.597^{* *}$ & $.368^{* *}$ \\
10 to 99 & $(.056)$ & $(.0399)$ \\
& $.661^{* *}$ & $.503^{* *}$ \\
100 or more & $(.097)$ & $(.0667)$ \\
& & $.174^{* *}$ \\
Constant & $.320^{* *}$ & $(.0185)$ \\
\hline Observations & $(.030)$ & 2477 \\
R-squared & 1522 & .061 \\
\hline \hline
\end{tabular}

Notes: Robust standard errors in parentheses.

${ }^{*}$ significant at $5 \% ;{ }^{* *}$ significant at $1 \%$ 
Table 4: OLS estimates: Other determinants of settlement amounts

Dependent variable: Cost recovery/costs

\begin{tabular}{|c|c|c|c|c|c|}
\hline & $(1)$ & $(2)$ & (3) & $(4)$ & $\begin{array}{c}\text { No offsite } \\
\text { PRPs } \\
(5)\end{array}$ \\
\hline \multicolumn{6}{|c|}{ Size classes of defendant count: } \\
\hline \multirow[t]{2}{*}{2} & $.118^{*}$ & $.121^{*}$ & $.123^{*}$ & $.143^{\dagger}$ & .146 \\
\hline & $(.052)$ & $(.052)$ & $(.051)$ & $(.086)$ & $(.100)$ \\
\hline \multirow[t]{2}{*}{3 or 4} & $.216^{* *}$ & $.229^{* *}$ & $.229^{* *}$ & $.337^{* *}$ & $.248^{*}$ \\
\hline & $(.054)$ & $(.054)$ & $(.054)$ & $(.091)$ & $(.115)$ \\
\hline \multirow[t]{2}{*}{5 to 9} & $.349^{* *}$ & $.380^{* *}$ & $.381^{* *}$ & $.302^{* *}$ & $.315^{* *}$ \\
\hline & $(.058)$ & $(.058)$ & $(.058)$ & $(.086)$ & $(.119)$ \\
\hline \multirow[t]{2}{*}{10 to 99} & $.581^{* *}$ & $.627^{* *}$ & $.633^{* *}$ & $.579^{* *}$ & $.361^{* *}$ \\
\hline & $(.055)$ & $(.056)$ & $(.056)$ & $(.081)$ & $(.139)$ \\
\hline \multirow[t]{2}{*}{100 or more } & $.670^{* *}$ & $.711^{* *}$ & $.721^{* *}$ & $.606^{* *}$ & $.760^{* *}$ \\
\hline & $(.096)$ & $(.097)$ & $(.098)$ & $(.126)$ & $(.284)$ \\
\hline \multirow[t]{2}{*}{ Multisite defendant share } & $.307^{* *}$ & $.308^{* *}$ & $.314^{* *}$ & $.359^{* *}$ & - \\
\hline & $(.059)$ & $(.059)$ & $(.059)$ & $(.086)$ & \\
\hline \multirow[t]{2}{*}{ Firm defendant share } & $.112^{*}$ & $.115^{*}$ & $.109^{*}$ & $.201^{* *}$ & - \\
\hline & $(.046)$ & $(.046)$ & $(.046)$ & $(.075)$ & \\
\hline \multirow[t]{2}{*}{ Costs (million $\$$ ) } & - & $-.0055^{* *}$ & $-.0055^{* *}$ & $-.0048^{* *}$ & - \\
\hline & & $(.0007)$ & $(.0007)$ & $(.0008)$ & \\
\hline $\begin{array}{l}\text { Cost of private cleanup } \\
(\text { million } \$)\end{array}$ & - & - & $\begin{array}{c}-.00075^{* *} \\
(.00025)\end{array}$ & - & - \\
\hline \multirow[t]{2}{*}{ Offsite PRP present } & - & - & - & $.136^{*}$ & - \\
\hline & & & & $(.062)$ & \\
\hline \multirow[t]{2}{*}{ Contamination since 1980} & - & - & - & -.0424 & - \\
\hline & & & & $(.0571)$ & \\
\hline \multirow[t]{2}{*}{ Estimated PRP expenditures } & - & - & - & $-.00213^{*}$ & - \\
\hline & & & & $(.00093)$ & \\
\hline \multirow[t]{2}{*}{ Constant } & $.160^{* *}$ & $.170^{* *}$ & $.174^{* *}$ & .088 & $.280^{* *}$ \\
\hline & $(.040)$ & $(.040)$ & $(.040)$ & $(.088)$ & $(.056)$ \\
\hline Observations & 1522 & 1522 & 1522 & 634 & 315 \\
\hline R-squared & .116 & .134 & .135 & .174 & .051 \\
\hline
\end{tabular}

Notes: Robust standard errors in parentheses.

$\dagger$ significant at $10 \%$; * significant at 5\%; ** significant at $1 \%$

Column (4) also contains a dummy variable for missing PRP expenditure data. 


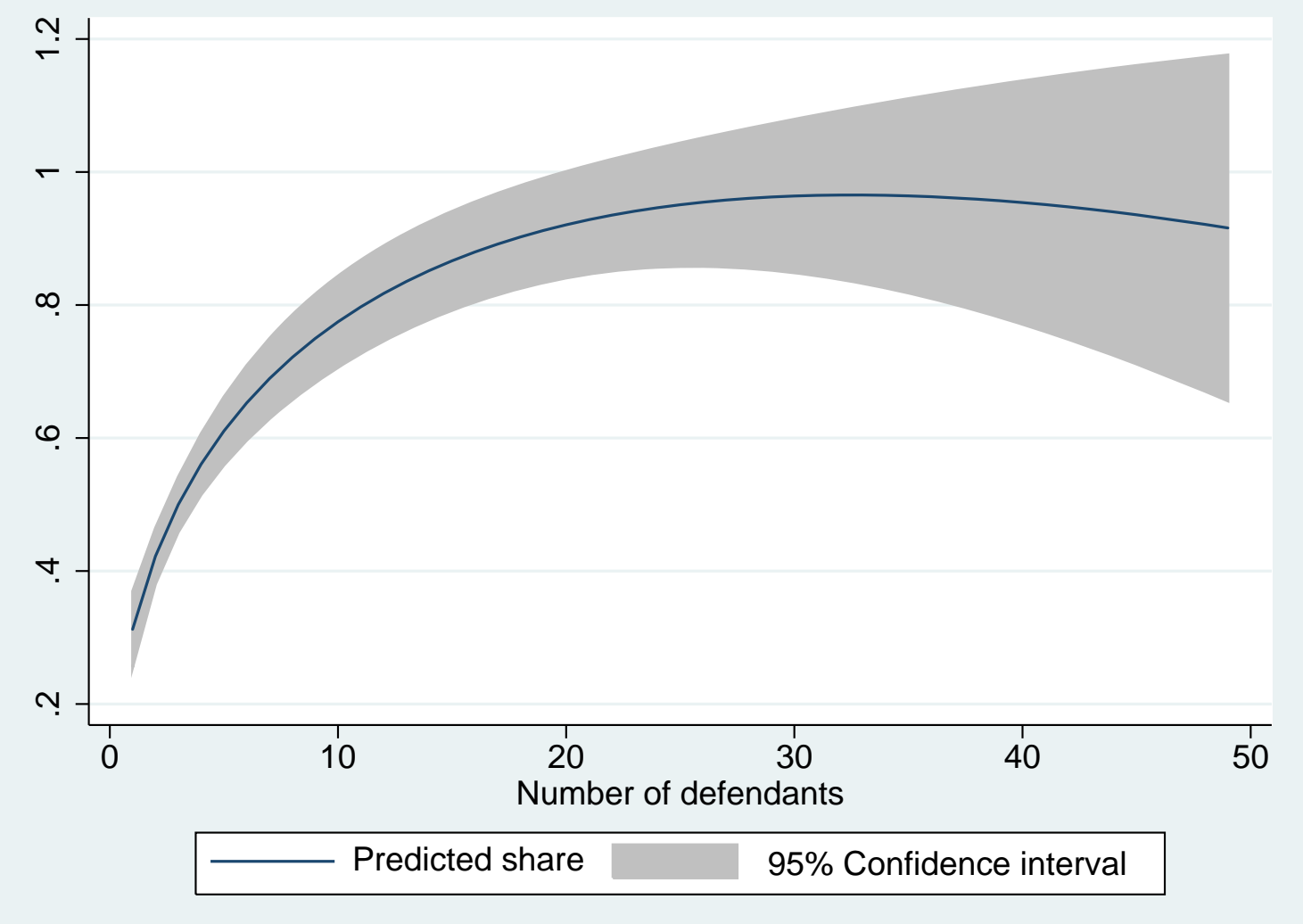

Figure 1: Predicted share recovered (fractional polynomial regression) 